\title{
ISOLATION AND DECLINE OF A POPULATION OF THE ORANGE-BREASTED FALCON
}

\author{
Robert B. Berry ${ }^{1,3}$, Craig W. Benkman², Angel Muela ${ }^{1}$, \\ Yeray Seminario ${ }^{1}$, And Marta Curti ${ }^{1}$ \\ ${ }^{1}$ The Peregrine Fund, 5668 West Flying Hawk Lane, Boise, ID 83709 \\ ${ }^{2}$ Department of Zoology and Physiology, University of Wyoming, Laramie, WY 82071
}

\begin{abstract}
Probably always rare and local because of its ecology and specialized habitat, the small, isolated population of the Orange-breasted Falcon (Falco deiroleucus) in Belize and Guatemala, likely numbering fewer than 40 territorial pairs, appears to be in steep decline in Belize. Territory occupancy ( $n=12$ eyries) in the population we studied in Belize declined from 83\% (1992 to 1997) to 54\% (2003 to 2009), and occupancy in 2009 was only half the mean in the prior decade. Mean annual production of fledglings per territorial pair declined $35 \%$ from 0.77 to 0.50 . Mean annual population productivity, which measures the combined effect of occupancy and fecundity, declined $57 \%$ from 0.90 to 0.38 . In contrast, neither occupancy nor fledging success in Guatemala $(n=7$ eyries) declined over the same time period. Historical records and recent surveys suggest that the Orange-breasted Falcon has been extirpated from much of Central America and southern Mexico and that its range is contracting in South America, despite large areas of apparently suitable habitat. We identify factors we think are contributing to this decline, especially human-related conflicts as well as competition for nest sites and depredation by increasing numbers of Black Vultures (Coragyps atratus). We suggest potential management solutions, including genetic restoration and the creation of safe harbors for nesting.
\end{abstract}

Key words: Belize, declining populations, Falco deiroleucus, Guatemala, raptor management, small populations.

\section{Aislamiento y Declive en una Población de Falco deiroleucus}

Resumen. La población pequeña y aislada de Falco deiroleucus en Belice y Guatemala ha sido probablemente rare y localizada debido a su ecología y hábitat especializado. Esta población, con posiblemente menos de 40 parejas, parece estar en claro declive en Belice. La ocupación de territorios ( $n=12$ nidos) en la población de nuestro estudio en Belice ha decrecido recientemente desde un 83\% (1992 a 1997) hasta un 54\% (2003 a 2009), y la ocupación en 2009 ha sido sólo la mitad de la ocupación media en la década previa. La producción anual media de volantones por pareja y por territorio ha disminuido en un $35 \%$ de 0.77 a 0.50 . La producción media de la población, la cual mide el efecto de la ocupación y la fecundidad, ha decrecido en un $57 \%$, de 0.90 a 0.38 . Sin embargo, no se aprecia un declive en ocupación o éxito reproductivo en Guatemala durante el mismo periodo. Los mapas de distribución y los censos poblacionales sugieren que $F$. deiroleucus ha desaparecido de la mayor parte de Centroamérica y México, y su rango de distribución está reduciéndose en Sudamérica, a pesar de que existe hábitat aparentemente idóneo. Identificamos algunos factores que pensamos pueden estar contribuyendo a este declive, especialmente conflictos de carácter antrópico, la competencia por lugares de nidificación y depredación por Coragyps atratus. Sugerimos posibles soluciones de manejo, incluyendo la restauración genética y la creación de lugares seguros para nidificar.

\section{INTRODUCTION}

Species such as the Orange-breasted Falcon (Falco deiroleucus) that are highly specialized ecologically and have small, isolated populations are prone to population declines and local extirpation (Brook et al. 2002, Kruger and Radford 2008). A counterpart of the cosmopolitan Peregrine Falcon (F. peregrinus), the Orange-breasted Falcon is a brilliantly colored, medium-sized falcon of unbroken neotropical forests.
This little known species is considered rare and may be the most sparsely distributed falcon in the world (Cade 1982, Whittaker 1996, Thiollay 2007), although its abundance and distribution are clouded by confusion with the much more common and similarly plumaged Bat Falcon (F. rufigularis) (Jenny and Cade 1986, Howell and Whittaker 1995, Berry et al. 2007).

Orange-breasted Falcons occupy territories year-round and typically are found in rugged and remote areas of towering

Manuscript received 17 January 2010; accepted 25 March 2010.

${ }^{3}$ Current address: 1122 Soldier Creek Road, Wolf, WY 82844. E-mail: rberry@wyoming.com

The Condor, Vol. 112, Number 3, pages 479-489. ISSN 0010-5422, electronic ISSN 1938-5422. (C) 2010 by The Cooper Ornithological Society. All rights reserved. Please direct all requests for permission to photocopy or reproduce article content through the University of California Press's Rights and Permissions website, http://www.ucpressjournals.com/ reprintInfo.asp. DOI: 10.1525/cond.2010.100012 
cliffs in river valleys or near water, associated with vast expanses of moist mature tropical and subtropical forest (Cade 1982, Jenny and Cade 1986, Baker et al. 2000). The only confirmed records of nesting in trees are four in Ecuador (emergent Ceiba sp. and Swietenia sp.; Jenny and Cade 1986; J. P. Jenny, pers. comm.) and one that failed in a Corozo Palm (Orbignya cohune) in Guatemala (Baker et al. 2000). In Belize and Guatemala, suitable cliffs are large with obscure ledges, potholes, and crevices that provide shade from the tropical sun's heat and safety from predators. The species is not known to nest in tropical savanna (Orange-breasted Falcon Database 2009). Some authors suggest that it may be a bird of edges, borders, and clearings, adjacent to montane forest (Hilty and Brown 1986, Ridgely and Greenfield 2001), but this inference may be more a function of convenient observations than of preferred habitat. We have found the Orange-breasted Falcon within a mosaic of habitats, including farmed fields, orchards, and pasture land, but only if mature forest is the dominant community.

Many tropical raptors, including the closely related Bat Falcon, hunt within the forest canopy, but the Orange-breasted Falcon is unique in hunting primarily above the canopy (T. J. Cade, C. M. White, pers. comm.), perhaps the most challenging environment for a bird-eating specialist. The species has long pointed narrow wings with unusually stiff rachises, a relatively short tail, and a heavy compact body with a deep sternum supporting powerful flight muscles (Cade 1982; RBB, pers. obs.). These features favor speed over maneuverability as the falcon preys upon a wide variety of small to mediumsized birds briefly exposed above the canopy or crossing a canyon, stream, or river valley (Baker et al. 2000). The female is the most heavily armed of all falcon species, possessing a massive, laterally compressed beak, thick powerful legs, and enormous feet relative to its body size, all attributes important for grasping and quickly dispatching dangerous quarry (Cade 1982). Females (mean body mass about $600 \mathrm{~g}$ ) have up to twice the mass of males, a difference corresponding to the female's dominant role in social relations and eyrie defense (Cade 1982; RBB, pers. obs.).

The species' longevity and maximum reproductive age are unknown. Data from captives and from other falcon species suggest a maximum lifespan of about 20 years, breeding at age 2 years, with a reproductive life of about 12 years for females, 17 years for males (Cade 1982; RBB, pers. obs.). The egg is unusually large, with the normal clutch of three eggs laid over 6 days, in contrast to four eggs laid over 7 days, as is typical of many falcon species, including the Peregrine (Cade 1982; RBB, pers. obs.). We have found that the Orangebreasted Falcon routinely lays a second clutch in response to loss of eggs or nestlings to predation.

Here, we present demographic data recorded during two decades of study in Belize and Guatemala. In addition, we summarize what is known about the species' past and present distribution in Central and South America, to examine geographic and temporal trends across its entire range.

\section{METHODS}

\section{STUDY AREA}

Our study population is centered in the Mountain Pine Ridge in western Belize, at about $17^{\circ} \mathrm{N}$ latitude. This high, granite plateau rises $1000 \mathrm{~m}$ above the surrounding lowlands and covers about $800 \mathrm{~km}^{2}$, constituting a distinct physiographic subdivision at the northern end of the much larger Maya Mountains. The latter highlands are about $120 \mathrm{~km}$ long and $64 \mathrm{~km}$ wide at the widest point, oriented northeast-southwest and extending about $32 \mathrm{~km}$ into eastern Guatemala. Because of the soil's high acidity, the vegetation is uniquely dominated by pines (Pinus caribaea and . oocarpa). The plateau is dissected by streams and deep canyons with hardwood vegetation extending into the valleys below (Johnson and Chaffey 1973, Means 1997). These canyons form an abundance of limestone and granite cliffs, a few of which are occupied by Orange-breasted Falcons.

The climate of the Mountain Pine Ridge is semitropicalsubtropical moist - with the highest parts classified as subtropical wet (Holdridge 1967). Average annual temperature is $23{ }^{\circ} \mathrm{C}$, annual rainfall about $2000 \mathrm{~mm}$, and average relative humidity $83 \%$ (Means 1997). Both the falcon and the resident birds making up its prey base breed during the hot dry season from February to May (J. Meerman, pers. comm.). In contrast to the Mountain Pine Ridge, the central and southern Maya Mountains are rugged and remote with abundant karst cliffs and a few large sinkholes, dominated by subtropical moist hardwood forest and virtually unpopulated by humans (R. Manzanero, pers. comm.).

In Guatemala, the resident falcon population appears limited to the Mirador Basin Cordillera in the department of Petén, along a limestone ridge that forms the southern boundary of the Maya Biosphere Reserve at $\sim 17^{\circ} \mathrm{N}$ latitude. The topography is gently rolling, broken in a few areas by steep karst terrain and rarely by large escarpments that provide nesting habitat (Baker 1998). Elevation ranges from 100 to $600 \mathrm{~m}$. Climate is lowland tropical with pronounced dry and wet seasons, as at Mountain Pine Ridge (Smithe 1966). Vegetation is semideciduous moist tropical forest, 25-30 m tall, with a closed canopy in well-drained areas, to a more open canopy 10-15 m tall in low-lying sites and frequent permanently flooded lowlands or "bajos" (Schwartz 1990, Herrera-MacBryde and VillaLobos 1997). Other potentially suitable habitat is found in the southwest portion of the Maya Mountains in Guatemala, an area of marginally suitable karst cliffs surveyed in the 1980s by J. P. Jenny (pers. comm.), who found no falcons. This area is now dominated by a network of roads, agriculture, and rural communities unlikely to support Orange-breasted Falcons.

\section{SURVEYS}

Our study builds upon a series of earlier investigations by The Peregrine Fund, Inc., which we summarize here. In 1978, J. Peter Jenny and Tom J. Cade began gathering information on the Orange-breasted Falcon primarily from museum 
specimens. The following year Jenny traveled to Belize, Guatemala, Ecuador, and Peru, beginning the first study of the species' natural history (Jenny and Cade 1986). From the 1980s through 1991, Peregrine Fund researchers concentrated studies on newly located territories in Guatemala and expanded the search for new sites in Belize (Jenny 1989, Whitacre and Jenny 1991). Aaron Baker began surveying in earnest for additional pairs in Belize and Guatemala in 1992 (Baker et al. 2000). Baker surveyed known eyries two or more times each year (1992-1997), early during courtship to determine occupancy (February-March) when adults are highly vocal and visible and later to assess fecundity just after fledging (June-July). Baker preferred to count fledged young rather than nestlings, which were often difficult to observe in deep potholes and ledges.

In 2003, AM and MC resumed surveys of Baker's eyries in Belize, typically visiting known territories four times during the breeding season to determine occupancy and fecundity; in 2008, YS assumed primary responsibility for the survey. These three authors surveyed all known eyries in Belize an average of 7 times per season (range: 2-18), with the exception of territories occupied by Bat Falcons, as the two species are not known to nest on the same cliff, and searched for new territories (March-July 2008; March-May and September 2009). With the exception of the Corozo Palm eyrie, which the falcons abandoned in 1994, they also surveyed Baker's eyries in Guatemala 2-5 times per season. They expanded surveys to major unexplored drainages on the eastern and southern slopes of the Maya Mountains as well as the eastern and central interior. We have not surveyed large portions of the southwest Maya Mountains.

\section{STATISTICAL ANALYSIS}

We compared the demographic data of the eyries Baker studied (1992-1997) to the same territories in Belize (2003-2009) and to all known and monitored territories in the Petén of Guatemala (2008-2009). We tested for changes in occupancy and the number of fledglings by using generalized linear mixed models (GLMMs) as implemented in package lme4 (Bates and Maechler 2009) in R (R Development Core Team 2009). When occupancy was the response, we assumed binomially distributed errors and used a logit-link function. When the number of fledglings was the response, we assumed Poisson errors and used a log link. In all models, we included decade of observation (1990s or 2000s) as a fixed effect and included individual eyrie (with replicated observations within decades) as a random effect: mean values presented in the text are based on the eyrie's mean per decade. We ran separate models for data from Belize and from Guatemala. The model for occupancy in Guatemala failed because of too little replication of data (only 2 years) from each eyrie in the 2000 s, so we used a paired $t$-test. We also used a paired $t$-test to test for a decline in the population's mean annual productivity between the 1990s and 2000 s, calculated for each eyrie as the product of mean occupancy and the average number of fledged young from occupied sites. We included only eyries that fledged young in at least one decade ( $n=8$ and 6 eyries, respectively, for Belize and Guatemala). We used a one-tailed test to test for a decline in productivity.

\section{SPECIES DISTRIBUTION AND ECOLOGICAL NICHE MAPS}

To examine trends in the species' distribution, we generated predictive habitat maps (ecological niche modeling) from bioclimatic, topographic, and land-use variables derived from distribution records (Orange-breasted Falcon Database 2009). We used seven bioclimatic variables from WorldClim (www.worldclim.org), as well as altitude and slope from the Hydro1K project (U. S. Geological Survey 2001), to characterize the Orange-breasted Falcon's habitat (del Hoyo et al. 1994, Baker 1998). We used an algorithm (Maxent: Phillips et al. 2004, Phillips 2006) that combines these variables with occurrence data to predict the species' habitat. We created two maps to represent historic distribution before 1970 and current distribution after 1970, with an overlay depicting breeding distribution. We resampled all data layers to a spatial resolution of $0.04^{\circ}$. For generating the ecological niche models, we selected $50 \%$ of the occurrence localities as training and testing, respectively, and used Maxent with the default parameters. The meaning and significance of parameterization details were described by Phillips et al. (2004) and Phillips (2006). We narrowed our estimates by trimming the broad-scale geographic projections of the niche model with suitable information on land cover and topography.

To represent the potential distribution of the species, we used a cut-off of $5 \%$ as the lowest probability value generated by Maxent. Using a global land-cover classification that best fits the species habitat (http://www-em.jrc.it/glc2000/), we trimmed these maps again. We overlaid variables on the map with ArcMap 9.2 projected to Universal Transverse Mercator Coordinated System zone 20S and the World Geodetic System 1984 spheroid (Lohmar 1988).

\section{RESULTS}

\section{SURVEYS}

Aaron Baker enlarged the scope of his study in Belize and Guatemala from 11 sites in 1992 to 19 in 1996: 12 in the Mountain Pine Ridge of Belize, one in the central Maya Mountains, and six in Guatemala (Baker et al. 2000). Our ground and aerial surveys in the central and southern Maya Mountains in 2008 and 2009 revealed five additional occupied territories, although we did not include these records in our statistical analysis because of insufficient data. Only two territories are located outside the mountain foothills in small islands of mature forest, one about $20 \mathrm{~km}$ to the northwest of the Mountain Pine Ridge, the second about $12 \mathrm{~km}$ south of the southern mountains. Surveys in the 1980s, 1999-2000 
TABLE 1. Territory occupancy and fecundity of Orange-breasted Falcons in Belize and Guatemala from 1992 to 1997 and from 2003 to 2009. Fecundity is the mean number of young fledged per active eyrie.

\begin{tabular}{|c|c|c|c|c|c|c|c|c|c|c|c|c|c|}
\hline & 1992 & 1993 & 1994 & 1995 & 1996 & 1997 & 2003 & 2004 & 2005 & 2006 & 2007 & 2008 & 2009 \\
\hline \multicolumn{14}{|l|}{ Belize } \\
\hline Territories surveyed & 6 & 6 & 11 & 11 & 12 & 12 & 10 & 8 & 10 & 8 & 8 & 12 & 12 \\
\hline Pairs observed & 6 & 5 & 9 & 9 & 11 & 9 & 5 & 8 & 6 & 6 & 7 & 7 & 6 \\
\hline Occupancy (\%) & 100 & 83 & 82 & 82 & 92 & 75 & 50 & 100 & 60 & 75 & 88 & 58 & 50 \\
\hline Fecundity & 1.17 & 1.40 & 1.00 & 0.62 & 1.14 & 0.56 & 1.00 & 0.14 & 0.60 & 0.33 & 0.86 & 0.62 & 0.67 \\
\hline \multicolumn{14}{|l|}{ Guatemala } \\
\hline Territories surveyed & 5 & 6 & 5 & 6 & 6 & 6 & - & - & - & - & - & 5 & 6 \\
\hline Pairs observed & 3 & 4 & 3 & 4 & 4 & 3 & - & - & - & - & - & 5 & 6 \\
\hline Occupancy (\%) & 60 & 67 & 60 & 67 & 67 & 50 & - & - & - & - & - & 100 & 100 \\
\hline Fecundity & 1.00 & 0.50 & 0 & 1.00 & 0.75 & 2.00 & - & - & - & - & - & 0.50 & 1.40 \\
\hline
\end{tabular}

(Thorstrom et al. 2002), and in 2009 in suitable habitat along the Río Dulce on the Guatemalan side of Belize's southern border have been unsuccessful, suggesting that the southern foothills of the Maya Mountains may be the southern limit of the northern population. Five of six territories discovered in the 1980s and 1990s in the Mirador Basin Cordillera of Guatemala were active in 2008 and 2009, and a seventh territory was added in 2009, the only new addition to the study population this decade.

\section{OCCUPANCY AND PRODUCTIVITY}

In Belize, occupancy at surveyed eyries declined from an average of $83 \%$ from 1992 to 1997 to $54 \%$ from 2003 to 2009 (Table 1; GLMM, df =109, $P=0.04$ ). Occupancy was $100 \%$ at eight of these eyries during the six years of surveys in the 1990s. All four eyries that were occupied only sporadically in the 1990s were abandoned by the next decade, and only half the territories occupied in the 1990s were occupied in 2009. The mean number of fledged young per territorial pair (fecundity) declined from 0.77 per territorial pair in the $1990 \mathrm{~s}$ to 0.50 in the $2000 \mathrm{~s}$, although this comparison was not statistically significant ( $35 \%$ decline: Table $1 ;$ GLMM, $d f=73$, $P=0.087$ ). We noted both an increase in the incidence of nest failure and a decrease in the number of fledged young per successful nest. For all occupied eyries, mean population productivity a measure that combines the effects of occupancy and fecundity, declined from 0.90 fledged young per eyrie from 1992 to 1997 to 0.38 from 2003 to 2009 (57\% decline: onetailed paired $t$-test, $t=2.09, \mathrm{df}=9, P=0.033$ ). Total numbers of young fledged offer a similar perspective: 41 young fledged over 6 years from 1992 to 1997, compared to 25 over 7 years from 2003 to 2009.

We did not find declines in occupancy, number of young fledged, or productivity in Guatemala, although our calculations during the later decade are based upon only 2 years of data (2008-2009). Eyrie occupancy increased from 50-67\% in the 1990 s to $100 \%$ in 2008 and 2009 (paired $t$-test, $t=2.33$, $\mathrm{df}=4, P=0.08$ ). Fledglings per territorial pair in the two decades did not differ $(\mathrm{df}=20, P=0.59)$, increasing slightly from 0.88 (1992-1997) to 0.95 (2008-2009). Results of surveys from 1979 to 1989 and in 1991 suggest both occupancy and productivity varied greatly, as in the 1990s (Jenny 1989, Whitacre and Jenny 1991, Baker et al. 1992).

\section{SPECIES DISTRIBUTION AND ECOLOGICAL NICHE MAPS}

Before 1970, the Orange-breasted Falcon was widespread in Central America and southern Mexico (Fig. 1a). Since 1970, an absence of records and a loss of predicted habitat suggest that the species' range in Middle America has contracted to small islands of habitat in Belize, Guatemala, and eastern Panama (Fig. 1b). The species' range in South America appears to be decreasing as well. Prior to 1970, the Orange-breasted Falcon was widely distributed east of the Andes south to northern Argentina (Fig. 1a). Since 1970, the species has been recorded along the eastern slope of the Andes, along the north coast in Venezuela, in Guyana, Surinam, and French Guiana, and in the lowland basins of Brazil and Venezuela (Fig. 1b). An absence of records after 1970 is most striking in western Venezuela, eastern Brazil, and Paraguay. Breeding records after 1970 are consistent with predictive mapping, with concentrations in Belize and Guatemala and a sparse distribution in Colombia, Ecuador, French Guiana, Guyana, Peru, and Venezuela (Fig. 1b). Three records after 1970 outside core habitat, as specified by ecological niche modeling, in Chile (1) and Argentina (2) represent vagrants (Orange-breasted Falcon Database 2009), suggesting that similar widely dispersed records before 1970 may also be of vagrants rather than of residents.

\section{DISCUSSION}

\section{POPULATION TREND}

Declines in occupancy and productivity in Belize over the last two decades and an apparent reduction in the species' range, especially in Middle America (Fig. 1), confirm that at least some populations have declined, some may have disappeared, and others are increasingly vulnerable. On the basis of the ratio of known occupied territories to the number of apparently 


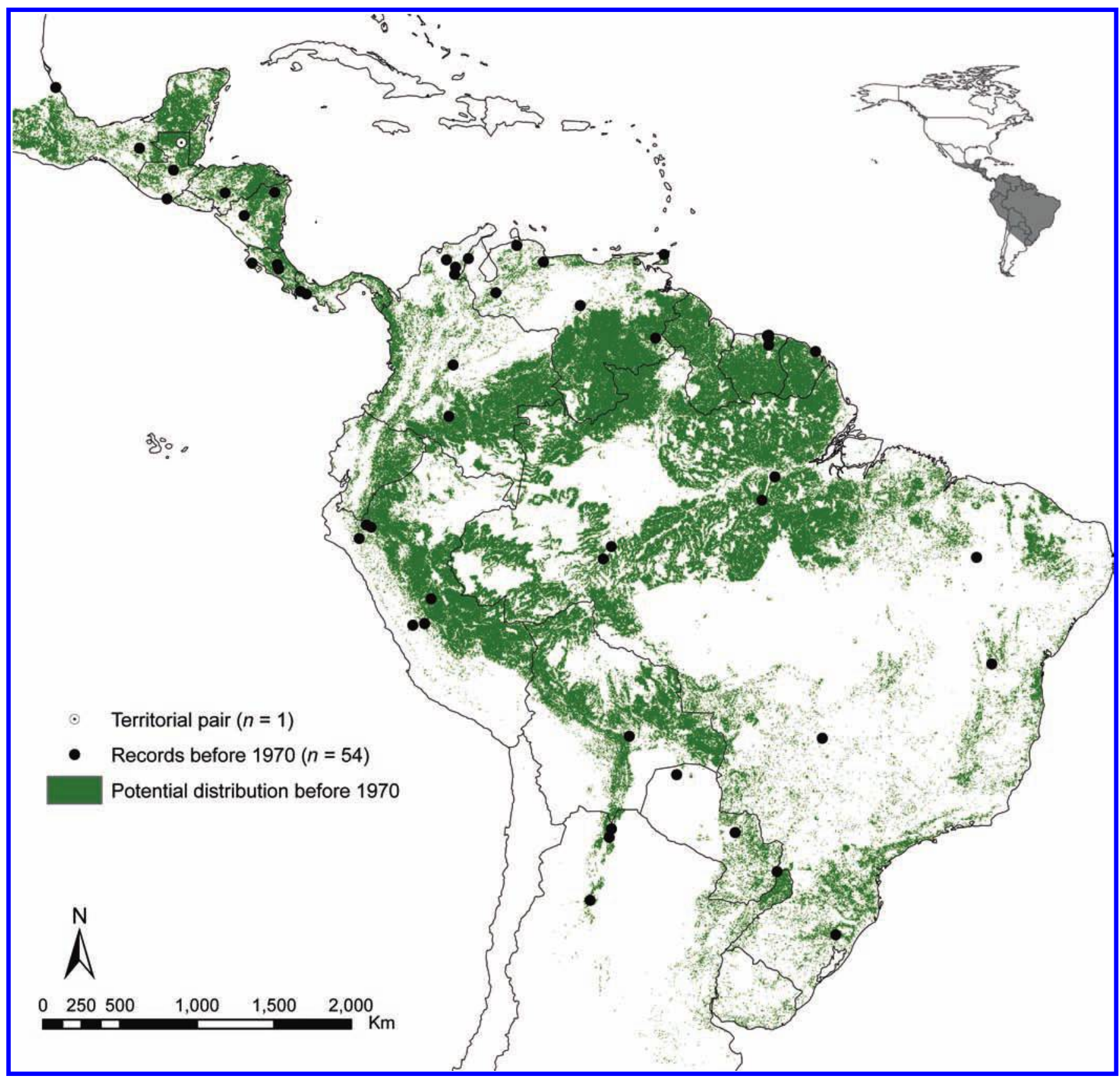

FIGURE 1. (a) Historical (1867-1969) and (b) current (1970-2009) locations from which the Orange-breasted Falcon is known, with breeding range (light green shading) and nonbreeding range (dark green shading) predicted by ecological niche modeling.

suitable cliffs and generous assumptions about habitat and occupancy for areas not yet surveyed, we estimate a maximum population of 38 pairs in Belize and Guatemala. Extensive ground and aerial surveys of 383 cliffs in seemingly suitable habitat in the Central American nations of El Salvador, Honduras, Nicaragua, Costa Rica, and Panama in 1999 and 2000 resulted in a single sighting of two falcons in the Darién Province of Panama (Anderson 1999, Thorstrom et al. 2002). Even if our population estimates are low, the population in Belize and Guatemala is small and likely isolated by nearly $1500 \mathrm{~km}$ from a few pairs (4) in eastern Panama (Thorstrom et al. 2002; Fig. 1b). Elsewhere in Middle America, the history of the species is unclear and is documented by only 10 museum specimens collected between 1867 and 1962 and a few confirmed sightings, without a single record of breeding (Baker et al. 2000, Global Raptor Information Network 2009; Fig. 1a). 


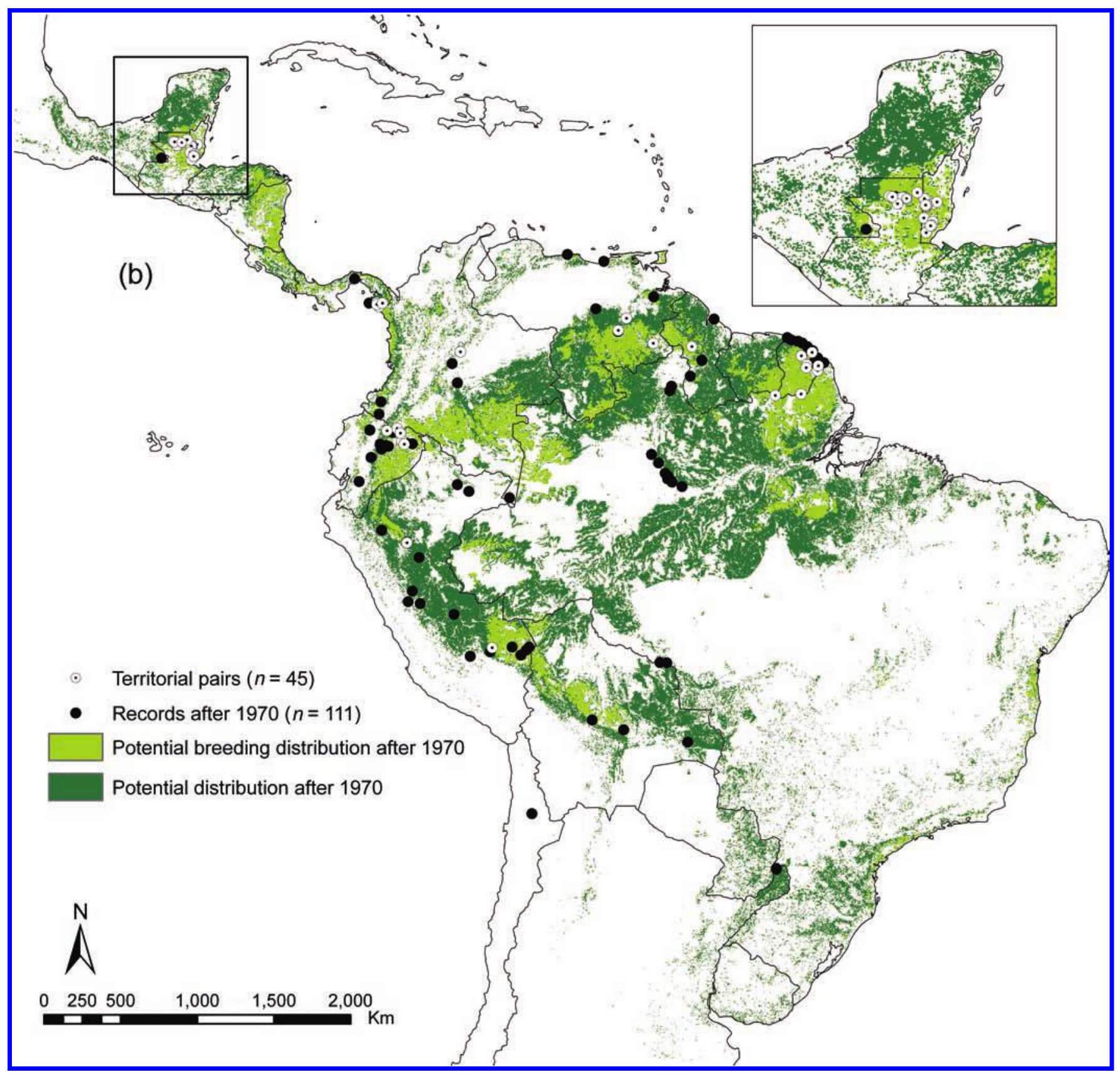

FIGURE 1. (Continued)

Most South American records before 1970 contain little information other than the location and date of collection (Orange-breasted Falcon Database 2009; Fig. 1a). Since 1970, the number of credible sight records by reliable birders has increased, especially on the eastern slope of the Andes (Fig. 1b), but there have been no focused studies. Only six breeding records have been verified by eggs or young (not delineated in Fig. 1b), although more than 20 potential territories have been identified (Orange-breasted Falcon Database 2009). Detailed accounts by professional ornithologists confirm that individuals (presumably juveniles and nonterritorial subadults) disperse far from breeding habitat, e.g., to Chile, Argentina, and Ecuador (Quito), and "winter" in coastal French Guiana and the lowland river basins of Amazonia (Fig. $1 \mathrm{~b}$ [records not delineated]; Whittaker 1996, 2003, Thiollay 2007; S. D. Strahl, unpubl. data). The species' distribution since 1970 suggests a reduction in range, which implies reduced numbers given the increased numbers of confirmed observations. Because 
the Orange-breasted Falcon is already so rare throughout its range, these apparent declines warrant further investigation. Reports to eBird (www.ebird.org), an international online database (Sullivan et al. 2009), are increasing and are verified through a questionnaire designed to ensure accurate identification and ecology, thus expanding our knowledge of the species' distribution throughout Latin America.

\section{POPULATION DYNAMICS AND MODELING}

Using Vortex 7.54 (Lacy 1993), Baker (1998) modeled the Orange-breasted Falcon population in Belize and Guatemala to simulate the effects of changes in mortality, fecundity, and carrying capacity, to estimate its probability of extinction. Baker assumed steady occupancy and fecundity, which characterized his study population in the 1990s, and also assumed 150 individuals (62 pairs), $45 \%$ juvenile and $15 \%$ adult mortality, and no inbreeding depression. The simulations suggested a stable local population and a probability of extinction in 200 years of 0.28 . Baker's model indicated that a mere $2 \%$ increase in juvenile and adult mortality increased the probability of extinction to 0.97 and that a decrease in fecundity of $2 \%$ or $5 \%$ increased the probability of extinction to 0.59 and 0.93 , respectively. We now believe that the size of the northern population is about half of what Baker assumed and that his estimate of juvenile mortality was low (Kauffman et al. 2003). A smaller population size, higher juvenile mortality, and a large (35\%) decrease in fecundity in Belize over the last two decades presage further decline.

The pattern of declining occupancy and nesting success in the Mountain Pine Ridge of Belize may be symptomatic of an aging population that lacks an adequate "floating" component of unmated replacements typical of healthy falcon populations (Hunt 1998). Senescence could explain why some Orange-breasted Falcon eyries are exceptionally productive one decade, fail in the next, and then resume productivity with the recruitment of a viable adult. Erosion of occupancy also suggests that there are few immigrants from Guatemala or the southern Maya Mountains.

\section{ANTHROPOGENIC THREATS}

The highly specialized Orange-breasted Falcon is not known to nest apart from mature forest, although we do not know the point at which fragmented habitat becomes uninhabitable or why. Small farms, orchards, and cattle ranching have created a mosaic of habitats in the mountain valleys surrounding the Mountain Pine Ridge, causing the abandonment of at least one falcon territory and potentially threatening three others. Construction at three hydroelectric dams along the Macal River, beginning in 1993 and continuing today, are implicated in the loss of two territories in the 1990s. These projects have exposed two currently active territories to a large force of migrant laborers, increased public access, the risk of electrocution and collision with power lines, and growing numbers of
Black Vultures (Coragyps atratus). In this decade, ecotourism may have caused the failure of a productive eyrie we have studied because of heavy use of an overlook directly above the eyrie, which is in a sinkhole. Nonetheless, as exemplified in Tikal National Park, the species seems indifferent to human activity outside its immediate nesting territory. Jenny and Cade (1986) speculated that the species' long-term viability might be incompatible with habitat alteration by humans, which may lead to direct persecution. In an area of Ecuador where Orangebreasted Falcons nested in trees in the 1980s, nest trees were logged, birds were displaced, and at least one pair was shot.

The Mirador Basin Cordillera is threatened by expanding rural communities and towns (Carmelita and Uxactun) and a higher rate of deforestation, colonization, agriculture, and subsistence hunting than in Belize. Negotiations to strengthen the legal protection for the Maya Biosphere Reserve, which includes the cordillera, are progressing (R. D. Hansen, pers. comm.), although planned new or improved roads (Ramos et al. 2007) may threaten up to $10 \%$ (189 $000 \mathrm{ha}$ ) of the MayaLacandón Important Bird Area (Eisermann and Avendaño 2009). Even though falcon occupancy and productivity appear stable, over time, the inevitable correlates of human progress are likely to have a greater negative effect.

\section{PREDATION}

In our study area, $55 \%$ of the falcon's nesting attempts $(n=94)$ failed. Many failures appear to be caused by predation, as the entire clutch disappears simultaneously. The list of potential predators is enormous, from jays and toucans to hawkeagles, owls, forest falcons, vultures, arboreal snakes, and small mammals.

Three predators may have a disproportionate effect on the Orange-breasted Falcon in Belize: the Black-and-White Hawk-Eagle (Spizaetus melanoleucus), the Stygian Owl (Asio stygius), and especially the Black Vulture. The hawk-eagle is the major predator of released falcons in Belize and likely depredated five captive-bred falcons and a wild juvenile. The Stygian Owl is a common bird-eating specialist of the pineoak forest (Lopes et al. 2004). A contraction in the owl's range from catastrophic loss of habitat in the Mountain Pine Ridge (1998-2002) (G. Headley, pers. comm.) may have concentrated the owls in the falcon's habitat, increasing predation, similar to intense predation by the Great Horned (Bubo virginianus) and Eagle Owls (B. bubo) on neighboring populations of the Peregrine Falcon (Newton 2003). The hawk-eagle (R. Thorstrom, pers. comm.) and the owl (Eisermann and Avendaño 2007) are rare or absent in the Mirador Basin of Guatemala.

The Black Vulture is the most ubiquitous and potentially threatening of avian predators. Cliffs and associated high hillsides are especially attractive to vultures for perching, soaring, and nesting. The Black Vulture is more predatory than the Turkey Vulture (Cathartes aura) and the much less common King Vulture (Sarcoramphus papa), foraging by sight and 
attacking and killing small animals and fledgling birds (Bent 1937). A group of Black Vultures can overpower the falcon's aggressive defense and consume eggs or young or appropriate a prime nesting cliff.

Despite that species' abundance, depredation by the Black Vulture is subtle, and its nesting is secretive. Nonetheless, we have seen vultures perched on nest ledges previously occupied by falcons, and in one instance large fledglings disappeared just prior to vultures occupying the site. The appearance of a large vulture chick in a pothole at our most productive eyrie in Belize explained the falcon's mysterious disappearance after two decades of occupancy. Black Vultures are also known to take over the nest cavities of Collared Forest-Falcons (Micrastur semitorquatus; Thorstrom et al. 2000) and Scarlet Macaws (Ara macao) (N. E. Seavy, unpubl. data).

Finally, Africanized bees (Apis sp.) have hives on many cliffs where the falcon nests. While climbing, we have been attacked by swarms of these aggressive bees, narrowly escaping serious injury or death. Feral Africanized bees arrived in Belize and Guatemala about 1986, displacing the local honey bee, swarming more and achieving much greater densities (Rogel et al. 1991, Clarke et al. 2002). These bees have had a serious effect on cavity-nesting species such as the Scarlet Macaw (Iñigo-Elias 1996).

We subjectively analyzed the security of individual eyries from vulture predation. Only one (8\%) of 12 historical nest sites in Belize, a deep horizontal crevasse beneath a rock overhang (see Fig. 2a), appears "safe." This eyrie fledged young in all 10 years it was surveyed, producing 21\% (14 of 66) of fledged young. All other sites are located on open ledges or in caves easily accessible to vultures (see Fig. 2b). In Guatemala, one (17\%) of six sites, a deep horizontal crevasse near the bottom of a large cliff, appears safe. Competition with Black Vultures for a nesting cavity in Tikal National Park resulted in the falcons abandoning the park from 1984 until 1995 (Jenny 1989). In 2007, the pair chose an alternate site. The nest failed, but installation in 2009 of a wire exclosure, allowing the falcons access, may have aided in the successful fledging of two juveniles (see Fig. 2c). These two eyries fledged chicks in 7 of 9 years in which they were surveyed and produced $54 \%$ (14 of 26) of the young fledged in Guatemala. The large number of surviving chicks from a few vulture-safe eyries suggests that predation from Black Vultures may explain, by itself, the relative stability of Guatemala's population.

\section{THREAT STATUS}

Kruger and Radford (2008) found that in the family Accipitridae the risk of extinction is greatest for populations that are small, specialized, and geographically limited, and that the relationship between a small population, range size, and a species' biology is what often leads to population declines. Their logic is as follows: (1) small population size increases the likelihood that genetic variation will diminish, resulting in a reduced probability of long-term survival, (2) small geographic ranges increase extinction probability for a variety of reasons including stochastic events such as hurricanes, (3) species with narrow habitat requirements are less capable of dealing with habitat transformation and fragmentation, (4) species with low

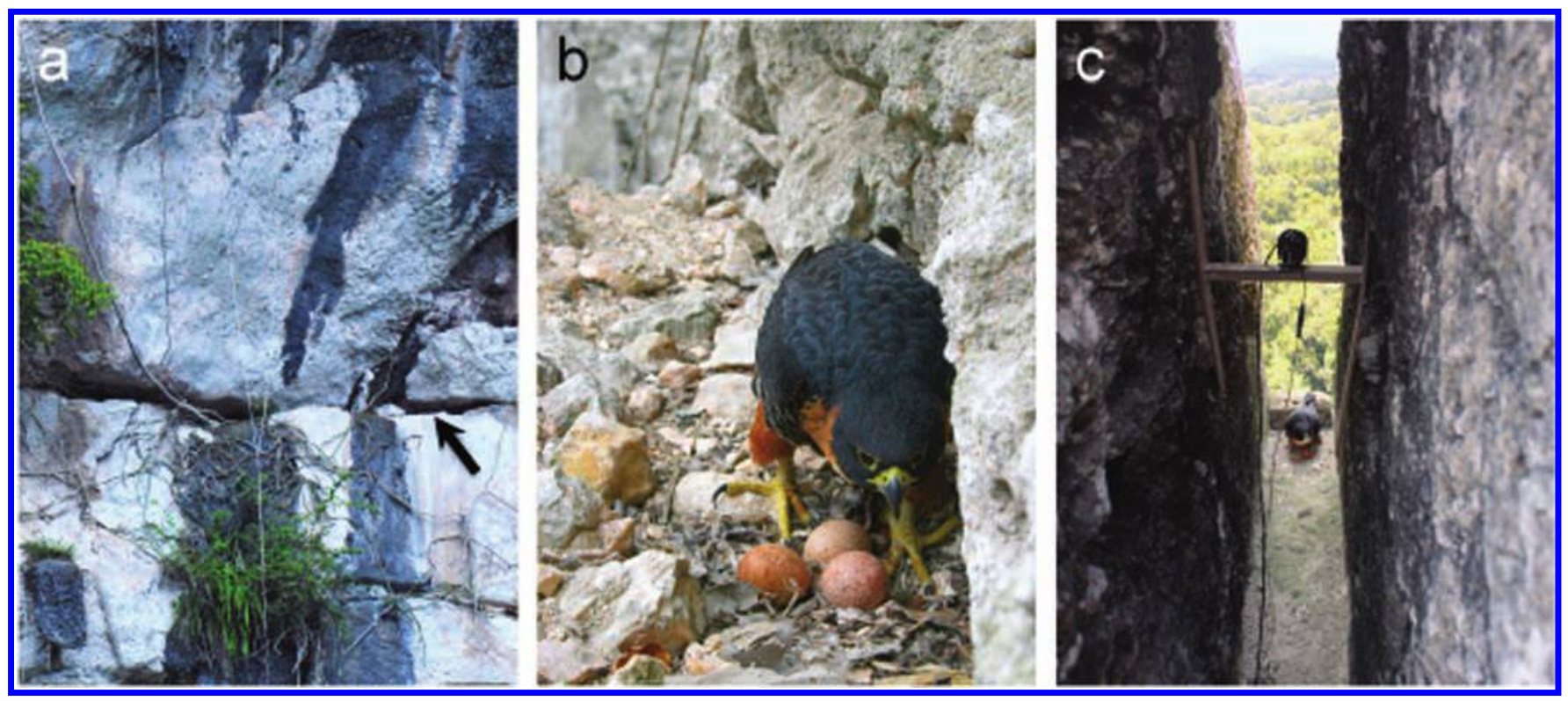

FIGURE 2. Relative safety of three Orange-breasted Falcon eyries from predation: (a) deep narrow labyrinth of caves providing safety and shelter to eggs and young (arrow points to eyrie location); (b) an open ledge visible to predators; (c) reasonably safe wind tunnel in a Mayan pyramid, wired at one end (behind from where photo was taken) to exclude vultures. Photographs by Robert B. Berry (a), Marta Curti (b), and Angel Muela (c). 
reproductive rates (e.g., small clutch size) are less able to reverse population declines, and (5) prey specialization and hunting method may limit survival opportunities. All of Kruger and Radford's extinction criteria apply to the Orange-breasted Falcon in Central America. Moreover, a combination of threats working simultaneously amplifies the risk of extinction (Brook et al. 2008, Laurance and Useche 2009). We believe that the drivers of the falcon's decline are habitat alteration and associated human activities, which include logging, agriculture, and development. These primary drivers act synergistically with the effects of human disturbance such as increased human access to remote habitat, hunting, tourism, selective logging, and collecting, further exacerbated by interactions with predators and dynamics intrinsic to small populations (see Brook et al. 2002, Tallmon et al. 2004, Kruger and Radford 2008).

The International Union for the Conservation of Nature (IUCN 2001) ranks a species' risk of extinction against established criteria to measure population size, rate of population decline, and geographic range size. In the 2008 Red List of Threatened Species, the Orange-breasted Falcon is ranked globally as a species of "least concern," in a category that includes taxa which are "widespread and abundant." The IUCN condones regional listings, especially if a species is isolated. The falcon population in Belize and Guatemala fits within the "vulnerable" category of threatened species. The species is widely distributed in South America but rare and local throughout its vast range, which appears to be contracting. Its status is largely unknown and is best categorized as "data deficient" or "near threatened."

\section{CONSERVATION}

To help predict future scenarios and facilitate proactive conservation, we have identified those attributes and threats that may predispose the Orange-breasted Falcon to extirpation from Belize. In small populations of birds, fitness characters related to fecundity include fertility, hatchability, and fledgling survival (Jones et al. 1995, Westemeier et al. 1998, Swinnerton et al. 2004). Reduced fecundity in the Belize population suggests the potential for reduced fitness from inbreeding depression. Many studies involving a wide range of organisms have demonstrated that a few unrelated immigrants can re-establish fitness by restoring adaptive genetic variation (Bijlsma 2000, Tallmon et al. 2004, Bouzat et al. 2008). Accordingly, we are experimentally introducing captive-bred falcons of Panamanian origin to the Mountain Pine Ridge of Belize to test if inbreeding depression might be reducing the falcons' productivity. These individuals have the potential to enhance genetic variation, stabilize recruitment deficits, and help mitigate further population declines.

Black Vulture control is logistically daunting and politically sensitive because of the vulture's value in management of human refuse. Efforts to mitigate the effects of any predator by supplemental feeding, relocation, or lethal means is controversial and impractical. Trapping and relocating vultures at
Tikal National Park was futile, as the birds returned, although relocation of dump sites did reduce the local population (A. C. Córdova, pers. comm.). The creation of safe nesting sites for falcons or modification of existing sites to exclude vultures is worthy of consideration and has been successful for a variety of raptors, especially when coordinated with the presence of captive-bred individuals likely to adapt to artificial nest sites and attract local residents as mates (Jones et al. 1995, Newton 1998, Cade and Burnham 2003, Jenny et al. 2004).

\section{CONCLUSION}

Many authors have reflected upon the Orange-breasted Falcon's rarity throughout its extensive range (Cade 1982, Jenny and Cade 1986, Hilty and Brown 1986, Howell and Whittaker 1995, Whittaker 1996, Ridgely and Gwynne 1989, Baker et al. 2000, Ridgely and Greenfield 2001, Thiollay 2007). We believe the species' specialized habitat requirements, low reproductive rate, and predation by a plethora of natural predators are the primary causes for its historic scarcity. The cumulative effects of habitat alteration, fragmentation, human conflicts, and increasing predation together may explain the large diminution in the species' range in Middle America and the current decline of the population in Belize. Given the species' multiple ecological challenges and its apparent isolation from falcons in South America, extirpation of the small population in Belize and Guatemala seems increasingly likely.

\section{ACKNOWLEDGMENTS}

We thank Andres Lira Noriega (University of Kansas) for preparing and drafting the ecological niche maps, Lloyd Kiff(The Peregrine Fund) who helped compile and Marshall Iliff and Brian Sullivan (Cornell Lab of Ornithology) who manage the Orange-breasted Falcon database. We thank John W. Fitzpatrick, W. Grainger Hunt, Tom J. Cade, Carlos Martínez del Rio, Michael Patten, Knut Eisermann, and Richard O. Bierregaard for editing the manuscript and offering helpful suggestions. We thank C. M. White, N. E. Seavy, S. D. Strahl, R. D. Hansen, A. C. Cordova, R. Manzanero, and M. Talluto for sharing their data. We are especially grateful for the invaluable support provided by the Hidden Valley Inn, the Roe family, and George Headley, eco-friendly property owners in the Mountain Pine Ridge of Belize.

\section{LITERATURE CITED}

Anderson, D. L. 1999. Tawahka Project, Honduras. 1999 field season report. Peregrine Fund, Boise, ID.

BAKER, A. J., J. P. JENNY, AND D. F. WhitACRE. 1992. Orange-breasted Falcon reproduction, density, and behavior in Guatemala and Belize, p. 217-224. In D. F. Whitacre and R. K. Thorstrom [EDS.], Maya Project: use of raptors and other fauna as environmental indicators for design, management, and monitoring of protected areas and for building local capacity for conservation in Latin America, progress report V. Peregrine Fund, Boise, ID.

BAKER, A. J. 1998. Status and breeding biology, ecology, and behavior of the Orange-breasted Falcon (Falco deiroleucus) in Guatemala and Belize. M.Sc. thesis, Brigham Young University, Provo, UT. 
Baker, A. J., D. F. Whitacre, O. A. Aguirre-Barrera, and C. White. 2000. The Orange-breasted Falcon Falco deiroleucus in Mesoamerica: a vulnerable, disjunct population? Bird Conservation International 10:29-40.

Bates, D., And M. Maechler [online]. 2009. Package lme4, version 0.999375-32: linear mixed-effects models using S4 classes. $<$ http://lme4.r-forge.r-project.org> (29 October 2009).

BENT, A. C. 1937. Life histories of North American birds of prey. Part 1. U.S. National Museum Bulletin 167.

Berry, R., C. Wood, and B. Sullivan [online]. 2007. Orangebreasted Falcon Falco deiroleucus, neotropical birds. Cornell Lab of Ornithology, Ithaca, NY. <http://www.birds.cornell.edu/ obf> (1 March 2010).

$\rightarrow$ Bijlsma, R., J. Bundgaard, And A. C. Boerema. 2000. Does inbreeding affect the extinction risk of small populations?: predictions from Drosophila. Journal of Evolutionary Biology 13:502-514.

Bouzat, J. L., J. A. Johnson, J. E. Toepfer, S. A. Simpson, T. L. Esker, AND R. L. WestemeIER. 2008. Beyond the beneficial effects of translocations as an effective tool for the genetic restoration of isolated populations. Conservation Genetics 10:191-201.

Brook, B. W., D. W. Tonkyn, J. J. O'Grady, and R. Frankham. 2002. Contribution of inbreeding to extinction risk in threatened species. Conservation Ecology 6:16.

Brook, B. W., N. S. Sodi, and C. J. Bradshaw. 2008. Synergie! among extinction drivers under global change. Trends in Ecology and Evolution 8:453-460.

CADE, T. J. 1982. The falcons of the world. Comstock/Cornell Uni versity Press, Ithaca, NY.

Cade, T. J., And W. A. Burnham. 2003. Return of the Peregrine. Peregrine Fund, Boise, ID.

Clarke, K. E., T. E. Rinderer, P. Franck, J. G. Quezada-Euán, AND B. P. OLDROYD. 2002. The africanization of honeybees (Apis mellifera L.) of the Yucatan: a study of a massive hybridizatior event across time. Evolution 56:1462-1474.

Del Hoyo, J., A. Elliot, And J. Sargatal. 1994. Handbook of the birds of the world, vol. 2. Lynx Edicions, Barcelona, Spain.

Eisermann, K., AND C. Avendaño. 2007. Lista comentada de las aves de Guatemala/Annotated checklist of the birds of Guate mala. Lynx Edicions, Barcelona, Spain.

EISERMANN, K., AND C. AVENDAÑo. 2009. Conservation prioritysetting in Guatemala through the identification of important bird areas, p. 315-327. In T. D. Rich, C. Arizmendi, D. Demarest, and C. Thompson [EDS.], Tundra to tropics: connecting birds, habitats and people. Proceedings of the 4th International Partners in Flight Conference, 13-16 February 2008, McAllen, TX.

Global Raptor Information Network [online]. 2009. The Peregrine Fund species account: Orange-breasted Falcon Falco deiroleucus. <http://www.globalraptors.org> (20 August 2009).

Herrera-McBryde, O., And J. Villa-Lobos. 1997. Petén region and Maya Biosphere Reserve, Guatemala. Central America CPD site MA13, p. 186-192. In S. D. Davis, V. H. Heywood, O. Herrera-MacBryde, J. Villa-Lobos, and A. Hamilton [EDS.], Centres of plant diversity: a guide and strategy for their conservation, vol. 3. IUCN Publications Unit, Cambridge, UK.

Hilty, S. L., AND W. L. BRown. 1986. A guide to the birds of Colombia. Princeton University Press, Princeton, NJ.

HoldRIDGE, L. R. 1967. Life zone ecology. Tropical Science Center, San José, Costa Rica.

Howell, S. N. G., AND A. WhitTAKer. 1995. Field identification of Orange-breasted and Bat Falcons. Cotinga 4:36-43.

$\rightarrow$ Hunt, W. G. 1998. Raptor floaters at Moffat's equilibrium. Oikos 82:191-197.
IÑIGO-ELIAS, E. E. 1996. Landscape ecology and conservation biology of the Scarlet Macaw (Ara macao) in Gran Petén region of Mexico and Guatemala. Ph.D. dissertation, University of Florida, Gainesville, FL.

IUCN 2001. IUCN Red List categories and criteria, version 3.1. IUCN, Gland, Switzerland.

JENNY, J. P., AND T. J. CADE. 1986. Observations on the biology of the Orange-breasted Falcon Falco deiroleucus. Birds of Prey Bulletin 3:119-124.

JENNY, J. P. 1989. Observations of the Orange-breasted Falcon (Falco deiroleucus) in the northern Petén from 1979 through 1989, p. 93-97. In W. A. Burnham, J. P. Jenny, and C. W Turley [EDS.], Maya Project: use of raptors as environmental indices for design and management of protected areas and for building local capacity for conservation in Latin America. Progress report II. Peregrine Fund, Boise, ID.

Jenny, J. P., W. Heinreich, A. B. Montoya, B. Much, C. Sandfort, AND W. G. HunT. 2004. From the field: progress in restoring the Aplomado Falcon to southern Texas. Wildlife Society Bulletin 32:276-285.

Johnson, M. S., AND D. R. ChafFey [ONLINE]. 1973. A forest inventory of part of the Mountain Pine Ridge, Belize. Resources study 13, Land Resources Division, Surrey, England. <http://library. wur.nl/WebQuery/isric/2829> (16 March 2010).

Jones, C. G., W. Heck, R. E. Lewis, Y. Mungroo, G. Slade, And T. CADE. 1995. The restoration of the Mauritius Kestrel Falco punctatus population. Ibis 137:S173-S180.

KAUFFMAN, M. J., W. F. Frick, AND J. LinTHICUM. 2003. Estimation of habitat-specific demography and population growth for Peregrine Falcons in California. Ecological Applications 13:1802-1816.

$\rightarrow$ Kruger, O., AND A. N. RadFord. 2008. Doomed to die? Predicting extinction risk in the true hawks Accipitridae. Animal Conservation 11:83-91.

LACY, R. C. 1993. Vortex: a computer simulation model for population viability analysis. Wildlife Research 20:45-65.

Laurance, W. F., and D. C. Useche. 2009. Environmental synergisms and extinctions of tropical species. Conservation Biology. 23:1427-1437.

$\rightarrow$ Lohmar, F. J. 1988. World geodetic system 1984, geodetic reference system of GPS orbits. Lecture Notes in Earth Sciences 19:476486.

Lopes, L. E., R. Goes, S. Souza, And R. De Melo Ferreira. 2004. Observations on a nest of the Stygian Owl (Asio stygius) in the central Brazilian cerrado. Ornitología Neotropical 15:423-427.

Means, D. B., 1997. Natural history of the Mountain Pine Ridge, Belize. Peregrine Fund, Boise, ID.

Newton, I. 1998. Population limitation in birds. Academic Press, San Diego.

Newton, I. 2003. The contribution of Peregrine research and restoration to a better understanding of Peregrines and other raptors, p. 337. In T. J. Cade and W. F. Burnham [EDS.], Return of the Peregrine. Peregrine Fund, Boise, ID.

Orange-Breasted Falcon Database. 2009. Historic and current records maintained jointly by the Peregrine Fund, Boise, ID, and Cornell Lab of Ornithology, Ithaca, NY.

Phillips, S. J., M. Dudik, AND R. E. Schapire. 2004. A maximum entropy approach to species distribution modeling, p. 655-662. In R. Greiner and D. Schuurmans [EDS.], Proceedings of the 21st International Conference on Machine Learning. ACM Press, New York.

Phillips, S. J. [ONLINE]. 2006. Maxent software for species habitat modeling, version 2.2.0. $<$ http://www.cs.princeton.edu/ $\sim$ schapire/ maxent/> (19 June 2009). 
R Development Core Team [online]. 2009. R: A language anc environment for statistical computing. R Foundation for Statistical Computing, Vienna, Austria. <http://www.R-project.org> (29 August 2009).

Ridgely, R. S., AND J. A. Gwynne, JR. 1989. A guide to the birds of Panama. Princeton University Press, Princeton, NJ.

Ridgely, R. S., And P. J. GReEnfield. 2001. Birds of Ecuador: status, distribution, and taxonomy, vol. 1. Cornell University Press, Ithaca, NY.

Rogel, V. G., A. Cesar-Dachary, and A. Sanchez-Vazquez. 1991. The impact of the africanized honey bee in north Belize. American Bee Journal 131:183-186.

Ramos, V. H., I. Burgués, L. Colombo Fleck, B. Castellanos, C. Albacete, G. Paiz, P. Espinosa, and J. Reid. 2007. Análisis económico y ambiental de carreteras propuestas dentro de la Reserva de la Biosfera Maya. Conservation Strategy FundConservación Estratégica Serie Técnica 8.

Schwartz, N. 1990. Forest society: a social history of Petén, Guatemala. University of Pennsylvania Press, Philadelphia.

Smithe, F. B. 1966. The birds of Tikal. Natural History Press, New York.

$\rightarrow$ Sullivan, B. L., C. L. Wood, M. J. Iliff, R. E. Bonney, D. Fink, AND S. KelLING. 2009. eBird: a citizen-based bird observation network in the biological sciences. Biological Conservation 142:2282-2292.

$\rightarrow$ Swinnerton, K. J., J. J. Groombridge, C. G. Jones, R. W. Burn, And Y MuNGROO. 2004. Inbreeding depression and founder diversity among captive and free-living populations of the endangered Pink Pigeon Columba mayeri. Animal Conservation 7:353-364.

$\rightarrow$ Tallmon, D. A., G. Luikart, And R. S. Waples. 2004. The alluring simplicity and complex reality of genetic rescue. Trends in Ecology and Evolution 19:489-494.
Thiollay, J.-M. 2007. Raptor communities in French Guiana: distribution, habitat selection, and conservation. Journal of Raptor Research 41:90-105.

Thorstrom, R., J. D. Ramos, And J. M. CAstillo. 2000. Breeding biology and behavior of the Collared Forest-Falcon (Micrastur semitorquatus) in Guatemala. Ornitología Neotropical 11: $1-12$.

Thorstrom, R., R. Watson, A. Baker, S. Ayers, and D. L. Anderson. 2002. Preliminary ground and aerial surveys of Orange-breasted Falcons in Central America. Journal of Raptor Research 36:39-44.

U. S. Geological SuRvey (USGS) [onLine]. 2001. HYDRO1k elevation derivative database. USGS, Washington, DC. $<$ http://gcmd. nasa.gov/records/GCMD_HYDRO1k.html> (19 June 2009).

$\rightarrow$ Westemeier, R. L., J. D. Brown, S. A. Simpson, T. L. Esker, R. W. Jasen, J. W. Walk, E. L. Kershner, J. L. Bouzat, and K. N. PAIGE. 1998. Tracking the long-term decline and recovery of an isolated population. Science 282:1695-1698.

WhITACRE, D. F., AND J. P. JENNY. 1991. Orange-breasted Falcon survey work in Guatemala and Belize, p 137-143. In D. F. Whitacre, W. A. Burnham and J. P. Jenny [EDS.], Maya Project: use of raptors and other fauna as environmental indicators for design and management of protected areas and for building capacity for conservation in Latin America. Progress report IV. Peregrine Fund, Boise, ID.

WhitTaker, A. 1996. First records of the Orange-breasted Falcon Falco deiroleucus in central Amazonian Brazil, with short behavioral notes. Cotinga 6:65-68.

WhitTAKER, A. 2003. Noteworthy ornithological records from Rondônia, Brazil, including a first country record, comments on austral migration, life history, taxonomy and distribution, with relevant data from neighboring states, and a first record for Bolivia. Bulletin of the British Ornithologists' Club 124:239-271. 